\title{
Hinduism, Hindutva and Hindu Populism in India: An Analysis of Party Manifestos of Indian Rightwing Parties
}

\author{
Raja M. Ali Saleem
}

check for updates

Citation: Saleem, Raja M. Ali. 2021. Hinduism, Hindutva and Hindu Populism in India: An Analysis of Party Manifestos of Indian Rightwing PartiesReligions 12: 803. https:// doi.org $/ 10.3390 /$ rel12100803

Academic Editors: Ihsan Yilmaz and Jeffery D. Long

Received: 25 June 2021

Accepted: 16 September 2021

Published: 26 September 2021

Publisher's Note: MDPI stays neutral with regard to jurisdictional claims in published maps and institutional affiliations.

Copyright: (C) 2021 by the author. Licensee MDPI, Basel, Switzerland. This article is an open access article distributed under the terms and conditions of the Creative Commons Attribution (CC BY) license (https:/ / creativecommons.org/licenses/by/ $4.0 /)$.
Centre for Public Policy and Governance, Forman Christian College, Lahore 54000, Pakistan; alisaleem@fccollege.edu.pk

\begin{abstract}
Since the rise of the Bharatiya Janata Party (BJP), a lot has been written on Hindu nationalism. Prime Minister Modi's ascendency has similarly resulted in a plethora of books and articles on Hindu populism. However, most of the literature does not distinguish between the two. Hindu nationalism and Hindu populism overlap, particularly in Modi's India and Modi's BJP, but they are not the same. In this article, after a discussion on Hinduism's affinity to populism, an attempt has been made to distinguish between Hindu nationalism and Hindu populism based on an analysis of Hindutva parties' election manifestos. Since independence, three Hindutva parties have made a name for themselves at the national level: Hindu Mahasabha, Bharatiya Jana Sangh (BJS) and BJP. Based on their importance and success at the national level, one manifesto of Hindu Mahasabha, two manifestos of BJS and four manifestos of the BJP were analyzed based on criteria chosen after literature review. The results show that while Hindu nationalism was strong and visible in early Hindutva parties (Hindu Mahasabha and BJS), Hindu populism was weak and sporadic. Interestingly, for the BJP, there is rise and then drop in Hindu nationalism while Hindu populism has consistently increased.
\end{abstract}

Keywords: India; Hinduism; populism; Hindutva; Modi; BJP; BJS; Hindu Mahasabha; RSS

\section{Introduction}

Prime Minister Modi's approach and strategy to deal with the COVID-19 pandemic has been universally acknowledged as a disaster. The second wave exposed the deficiencies of his leadership style and his overall grasp of problems facing his 1.3 billion people. Many experts are blaming it on his populist politics and pointing as evidence to other populist leaders, such as Presidents Trump and Bolsonaro, who also failed to manage the pandemic (Collinson 2021; Friedman 2021; Santoshini et al. 2021). Others have criticized his Hindutva ideology, disregard for science and constitutionally ordained secularism and the othering of minorities that divided the nation instead of uniting it against the pandemic (Guha 2021; Viswanath 2021). Hindutva and Hindu populism have been part of Modi's success story from the start. He is a man from a very humble background who dethroned the famed Nehru-Gandhi dynasty and their party, the Indian Nation Congress, which was the dominant political party in India for more than fifty years. While Modi is not the first Hindu nationalist Indian prime minister, he is certainly the first one who has used both Hindu nationalism and populism. Although there has been a plethora of scholarship on Hindu nationalism, Hindu populism is mostly studied as an auxiliary component of Hindu nationalism or of the broader rightwing ${ }^{1}$ populist movement that has taken the world by storm during the last decade. There is a need to trace Hindu populism's history in India and to distinguish it from Hindu nationalism.

\section{Religion and Populism}

Populism is a concept that is difficult to define and highly contested. Populism can be leftwing or rightwing and it can instrumentalize the majority religion and exacerbate 
religious conflicts in the society or it can stay away from religion. It can be national or civilizational (Brubaker 2017). Scholars have defined it based on ideology, rhetoric or policies but no definition can accommodate the protean concept and efforts to conceptualize this intriguing idea are continuing (Yilmaz and Morieson 2021; Mackert 2019; Plagemann and Destradi 2019). For this article, populism refers to a kind of politics that divides the population into two parts, a small, corrupt ruling elite and an oppressed, exploited pure majority. Sometimes, besides this vertical dimension, there is also a horizontal dimension where the righteous majority is threatened by perfidious insiders and outsiders that are in cahoots with the corrupt elite. A temporal dimension is often also part of the populist politics where populist leaders disown and repudiate the present while singing about the glories of an imagined past and an impending future if the populist leader is allowed to lead.

Before the 1970s, for almost a hundred years, secularization theory was the dominant sociological paradigm. The major assumption of the theory was that religion would gradually decline as human societies progress. Its role in the public sphere would probably completely disappear while its role in the private sphere would be limited. The idea seemed to make sense as the increased knowledge about nature, scientific and technological progress, pluralization of religious field, functional differentiation, enlightenment, theory of evolution, more archaeological data falsifying religious myths, sexual revolution, etc., made a modern person less amenable to accept certainties of divine edicts. The functions that religion used to perform in the ancient and medieval world were performed by secular concepts in the modern world. The secularization of Western Europe, since the 17th century, seemed to be the model that other regions were destined to follow as they moved up the ladder of human progress.

The 1970s, however, reasserted or re-established the role of religion not only in the private sphere but also in the public sphere. The Iranian Revolution, emergence of the moral majority movement in US politics and rise of religious parties and fundamentalist movements in many developing countries were few of the many indications of the change. The re-emergence of religion that was supposed to be consigned to the dustbin of history as a key explanatory factor in domestic, regional and international politics was surprising for many scholars (Grzymala-Busse 2012). The 1980s and 1990s came up with further evidence of the impact of religion on politics. The religious fervor and avidity of Pope John Paul II, President Reagan and Islamist mujahideen in the fall of Communism and the Soviet "evil" empire was critical. These developments perhaps forced Samuel Huntington to come up with his controversial theory of "Clash of Civilizations", where civilizations are primarily defined on the basis of religion (Huntington 1993). The start of the 21st century totally debunked secularization theory or thesis as $9 / 11$ attacks made religion one of the most significant factors in international politics, although there are still some scholars that believe in a much-diluted form of the secularization theory.

The growing prominence of religion as a political ideology is manifest around the world now. Whether it is the coronavirus pandemic, migration, poverty, inequality or racial and gender discrimination, religion is present, either as cause or as a solution. Major international conflicts, such as India-Pakistan or Israel-Palestine or the division of Ukraine, cannot be understood without comprehending their religious dimensions. Not surprisingly, religion has also been employed by the populist leaders. One aspect of religion that is particularly useful for populists is the divisive binaries that religions create by their "usthem" rhetoric (Yilmaz et al. 2021; Hadiz 2018; Yilmaz and Bashirov 2018). According to Yilmaz and Morieson (2021), populism and religion has formed a close association in various countries of the world because of the following reasons:

Because populism, by its very nature, attaches itself to "thick" ideologies, it is often combined with religion. This attaching of populism to religion helps populists turn religion into a tool of power consolidation within societies in which religion already plays an important social role. Beyond this, populisms' Manichean character, or its division of the world into categories of "good" and "evil", mimics religion. Yet populism, even when 
not attached to a religion, may act as a kind of secular faith insofar as it sacralizes "the people", raising them above the "evil" and corrupt elites and other populists charge with being "enemies of the people". Equally, populism may attach itself merely to one aspect of religion: religious identity. Populism may therefore become identitarian and place people in categories of "good" and "evil" based on their religious identification (as opposed to their actual religious beliefs and practices).

Hinduism is one of the great religions of the world. This article examines how Hinduism has been used by Indian rightwing political parties to propagate their populist politics. Here, it is important to distinguish between Hindu populism and Hindu nationalism. Hindu nationalism, or Hindutva, is broadly the idea that Hindu religious or cultural identity is the national and primary identity of Indians. All other identities are subservient to the Hindu identity. It also advocated assimilation of religious minorities and acceptance of Hindu culture by them as their own culture. Hindu nationalism has always been anti-Muslim, the largest religious minority in India. Hindu populism is the use of Hindu nationalism or Hindutva as the basis of populist politics (Jaffrelot 2007). So, despite a large overlap between the two concepts, they are not one concept. It is possible to be a Hindutva politician without being a populist and vice versa. Unsurprisingly, the following debate will show that rightwing political parties in India preferred Hindu nationalism and Hindu populism.

This article is divided into three sections. In the first section, Hinduism's affinity with populism is discussed. As there are large differences between great religions, it is understandable that some religions maybe more suited to populist politics than others. The next section details a brief history of populism in India. The final part analyses seven manifestos (one of Hindu Mahasabha, two of BJS and four of BJP) of Hindu rightwing parties to ascertain the rise and fall of primarily Hindu populism but also of Hindu nationalism.

\section{Hinduism's Affinity with Populism?}

Is Hinduism a religion? This seems to be an absurd question when more than one billion people in the world claim to be Hindus. Hinduism is the third largest religion and the largest of non-Abrahamic faiths. But many Hindus might also deny there is a religion called Hinduism. They would prefer to call their religion Sanatana Dharma (translated as eternal order, way or duty). Some will call it the Vedic Dharma or even Hindu civilization, culture or way of life. The debate about the name can inform one about the diversity of practice in Hindu Dharma. Unlike Abrahamic or Semitic religions, there are thousands of gods, numerous books, no clear founder, no agreed origin story or dogma, etc. Some have been daunted by this complexity while others have called it the beauty of Hinduism:

Like all religious traditions, Hinduism is very diverse. However, it can be said that the diversity of Hinduism is of a completely different order to the diversity found in other religious traditions. The reason for this claim of radical diversity is that Hinduism has no founder figure or foundational event, no universally accepted canon of texts, no credal statement and no overarching institutional structure. There is no single source of authority that universally applies to all Hindus for all times. There is nothing that you can say about Hindus or Hinduism without some form of qualification. This has led some commentators such as Von Stietencron (2001, p. 33) to suggest 'our problems would vanish if we took "Hinduism" to denote a socio-cultural unit or civilization that contains a plurality of distinct religions'. (Jacobs 2010, pp. 6-7)

Christians and Muslims can be defined as people who follow Jesus Christ or Prophet Muhammad's teachings. There is no similarly simple way to define Hindus because of their diversity. There are few, if any, specific qualities that can help an expert identify Hindus. While idol-worship, vegetarianism, sacredness of cow, belief in karma (view of causality where good (bad) ideas and actions result in good (bad) consequences), samsara (cycle of 
birth, death and rebirth) and moksha (release) seem to be essential for being a Hindu, they are not (Flood 1996, pp. 5-8). David Frawley in his book What is Hinduism? writes:

Most of us with a little reading can define the main principles and beliefs of Christianity, Islam, Judaism or Buddhism. We can study the life of Christ, Mohammed, Moses or Buddha as a model for the religion as a whole. But how many of us, even those who may have studied Yoga and Vedanta, can define the essence of Hinduism? How many of us are aware of its true nature as Sanatana Dharma or the universal Dharma? How many of those born as Hindus know the roots of their own tradition? The very beauty of Hinduism is that it cannot be defined in a simplistic manner. It contains all the mystery and complexity, magic, wonder and enigma of life itself. (Frawley 2018, p. 40)

Scholars have argued that Hinduism's inclusivity, adaptability and complexity are the characteristics that have allowed it to stay as the majority religion of India even after more than a millennium of subjugation (Tharoor 2018). So, measuring it on the basis of criteria defined by Semitic religions is unfair. In many aspects, Hinduism can be considered a more modern religion than Judaism, Christianity and Islam.

'Hinduism' is a modern word for the world's oldest and still third-largest religion, with around one billion followers. And yet it differs from all of the 'Abrahamic' faiths-Judaism, Christianity and Islam-in the most fundamental of ways. Otherwise known as Sanatana Dharma ('the Eternal Truth'), 'Hinduism' is not an ethnically exclusive religion and it understands itself as inclusively embracing the partial truths of other religions from within a higher, holistic perspective. In contrast, Judaism is both an ethnically and doctrinally exclusive religion, whereas Christianity and Islam are ethnically inclusive but doctrinally exclusive faiths. (Wilberg 2009, p. 30)

Hinduism's lack of clear boundaries and dogma makes it different from Semitic religions. Even on one of the basic tenets regarding the creator or supreme being, so many options are available. Not only is there an option to choose from millions of gods but there are also options in terms of the relationship of god(s) to the world. In Semitic monotheistic religions, God is an omniscient, all-powerful Creator who is continuously engaged with the world. Nothing can happen without his knowledge and approval and he is always listening to people's prayers. A major difference between Semitic monotheisms and Hinduism is that in Hinduism, religious worldview does not revolve around God or gods. The purpose of the universe or the creation of human beings are not directly related to god(s). This creates ample space for differing types of relationships between god(s) and universe or human beings. For instance, in one Hindu tradition, the world depends on god but god is not dependent on the world, however, god is not separate from the world. Both are joined as the world is depicted as god's body. Another philosophy imagines god existing independently of the world, so the idea of the world as god's body is discarded. Still another ancient tradition rejects the division between an independent god and a dependent world, and claims that only one interconnected reality (Brahman, the supreme God) exists and the rest is all illusion (Saleem 2019).

S. N. Balagangadhara (1994) and the Ghent School take it one step further and argue that because of the absence of church, scriptures, beliefs in God, etc., Hinduism is not a religion. He claims that because Indian traditions lack attributes that make a religion a religion, these traditions are not religious. Europeans are not projecting their imagination when they "see" or define Hinduism, rather it is a shared ordered experience. Hinduism is "an experiential entity: an entity-in-experience or pattern that orders the western cultural experience of India." There is no Hinduism or Hindu identity (Roover 2019).

The key question, as far as this article is concerned, is whether such plurality and ambiguity make Hinduism a more or less amenable vehicle for populism. Numerous scholars have argued that populism is a thin ideology. It is not associated with a particular economic agenda, political program or social policies. A conservative military dictator 
and a socialist progressive political leader can both be populists (Yilmaz and Saleem 2021). As discussed above, when it comes to religion, populist leaders usually choose religion to "thicken" their ideology and to give a program to their rhetoric. Demand of imposition of religious law or some specific provisions of religious law to employ religious sentiments and to claim that a moral majority has been victims of an alliance between secularists and religious minorities has been a political strategy of a large number of populists. Starting from President Trump to President Erdogan to Prime Minister Modi and Imran Khan, all of these leaders have instrumentalized religion, without being religious leaders themselves (Brittain 2018; Yilmaz 2018, 2021; Yilmaz and Saleem 2021; Yilmaz and Shakeel 2021). Religious demands made their politics an aura of respectability and connected them to a long history of religious leaders and their struggles. With modernity and state gradually contesting religion's presence in the public sphere around the world, there was no shortage of resentment among the believers and devotees against the present order. Instrumentalization of Hinduism was, however, problematic, as it is itself a thin ideology. One can find few things that all Hindus agree on. Over the years, there are attempts to semitize or sanitize Hinduism. During the last 125 years, rightwing Hindus has tried to give a structure to Hinduism. While they keep on praising the all-embracing and all-inclusive qualities of Hinduism, they have tried to get Hindus to at least agree on some things because they need these things to unite Hindus and to prove that Hinduism is in danger. Cow protection was one of first things they latched onto and, since then, they have embraced the following ideas to the exclusion of millions of others: Ram/Krishna, Bhagavad Gita, Akhand Bharat, Hindi, Ayodhya Mandir, hatred for aggressive militant foreign invaders who, because of Hindus' inherent peacefulness, were able to desecrate the holy land and pure Hindu women, etc. (Tharoor 2018; Doniger 2009, pp. 654-90). Hindu nationalists made Hinduism into a thick ideology which was, later on, used by Hindu populists:

Hindus of this persuasion have attempted, as Amartya Sen eloquently expressed it, 'to miniaturize the broad idea of a large India_proud of its heterodox past and its pluralist present-and to replace it by the stamp of a small India, bundled around a drastically downsized version of Hinduism'. (Doniger 2014, p. 144)

Basu (2020, pp. 1-10) calls this "miniaturization" a quest for Hindu political monotheism, a protracted genesis of Hindu political identity (or Hindutva) spanning the nineteenth and twentieth centuries. This quest seemed necessary for the construction of a Hindu nation and a Hindu state. Tripathi (2009) also narrated how Hindu extremists have gradually tried to structure the amorphous concept of Hinduism into something similar to Abrahamic religions. Romila Thapar, similarly, argues that there is an attempt to make indigenous (Hindu) religions into a monolithic, structured, uniform religion which is foreign to Hinduism itself and the early culture of India. Thapar has called this new form syndicated Hinduism:

Syndicated Hinduism draws largely on reinterpreting Brahmanical texts of which the Gita is an obvious choice, defends the Dharmasastras and underlines a brand of conservatism in the guise of a modern, reformed religion. The model is in fact that of Islam and Christianity. There is a search for a central book and recently, on the wave of the Ramjanmabhoomi agitation, there has been focus on the Ramayana with the insistence on the historicity of Rama which makes him into a founder. (Thapar 2000, p. 1047)

This structured, syndicated Hinduism has not only formed the basis of Hindu nationalism but has also provided a somewhat "thick" ideology to support Hindu populism. Modi's combination of Hindutva and Hindu populism is probably possible only with the acceptance of structured Hinduism by millions of Hindus and the maturing of Hindutva. Hinduism, due to its amorphous nature, was not inherently suited to religious populism but it was "reformed" and "uniformed" to make it apposite for the task. 


\section{History of Hindu Populism}

India has a long history of Hindu populism. But populism in India has not been defined in numerous different ways. Populism in India is not only about fighting a corrupt elite for the righteous masses but also giving freebies to people to get their votes. The latter type of populism is usually associated with the Indian states in the south, particularly Tamil Nadu, but it is everywhere (Subramanian 2007). Last year, before state elections, capital Delhi's Chief Minister was accused of indulging in this type of populism (Pandey and Krishna 2020). More recently, an article in the Hindustan Times demonstrates the hold of populist politics in Tamil Nadu before elections on 6 May 2021:

From promises of free laptops to colour TVs and grinders, Tamil Nadu's political parties have tried to outdo each other in offering freebies ahead of the polls for decades. This time, the parties appear to be competing to rally women with pledges specific to them. Actor-politician Kamal Haasan, who launched his Makkal Needhi Maiam (MNM) in 2018, has promised to monetise the household work that women do. Last week, Dravida Munnetra Kazhagam (DMK) chief MK Stalin announced they would pay women households heads ₹1000 monthly if voted to power. The following day, chief minister Edappadi Palaniswami announced ₹1500 monthly for women if the ruling All India Anna Dravida Munnetra Kazhagam (AIADMK) retains power. (Chandrababu 2021)

Jaffrelot and Tillin (2017) take a middle of the road approach and include this freebie politics in their effort to understand and explicate populism in India. They identify three key types of populist politics in India. Two types are focused on political leaders, Prime Ministers Indra Gandhi and Narendra Modi, while the third one is regional, based on the southern states of Tamil Nadu and Andhra Pradesh. Indira Gandhi populism in the 1960s was a way to establish herself as a political heir to her father, Pandit Jawaharlal Nehru. There were many senior leaders, with decades of experience and service to the country and the Congress Party, who considered themselves more legitimate successors to Nehru. Indira Gandhi successfully defeated them by directly appealing to the masses. Prime Minister Nehru had more or less allowed the regional leaders of the Congress Party broad autonomy, and this has given them power. Nehruvian politics was not populist as he appealed to the higher ideals and for most part was reluctant to exploit the baser instinct of the people. It was the regional leaders that used populist politics to win elections. One of such regional leaders was Charan Singh, who is still remembered as the leader of Indian peasantry for his successful fight for peasant rights, both inside and outside the ruling Congress Party. Indira had to reach out to people, without taking the help of these regional leaders and many senior national leaders, such as Morarji Desai. She decided to adopt socialist populist policies and her slogan in the 1971 elections was gharibi hatao, or eradicate poverty. Jaffrelot and Tillin's second type is Hindu populism of Prime Minister Modi, which will be discussed in detail later in the article. The third type of Indian populist politics, according to Jaffrelot and Tillin, is the welfare populism in South India that is based on cultural regionalist identity politics. Here, along with the freebies, popular leaders $\mathrm{M}$. G. Ramachandran in Tamil Nadu and N.T. Rama Rao in Andhra Pradesh, who had made their mark in regional films, rallied the masses against the northern Hindi-belt dominated Congress Party.

Chakrabarti and Bandyopadhyay (2021) in their article on Indian populism, in contrast to Jaffrelot and Tillin, give more importance to populist policies than populism. They move closer to the popular Indian definition of populism where redistributive policies that are not directly or purely growth oriented are considered populist policies, especially when such policies are announced close to the elections. They inform briefly about Indira Gandhi's policies to attract votes and to bolster her claim of being the voice of people and the nation, "India is Indira and Indira is India," Congress's recent ten-year rule (2004-2014) and current PM Modi's populist rhetoric. In the last part, they discuss specific populist policies.

As is clear from the discussion above, these articles do not focus on Hindu populism. This article intends to fill the gap and study Hindu populism. It will be divided into four 
parts. The first part will discuss the pre-independence period. The second part will focus on the period from 1947 until the 1980s. The third part will focus on pre-Modi BJP Hindu populism and the last part will discuss Modi's Hindu populism.

\section{Hindu Populism before Independence}

While talking about the rich history of populism in India, Chakrabarti and Bandyopadhyay (2021) mention Mahatma Gandhi's self-sufficient agro-artisanal romanticism movement under the British Raj. They talk about it as populist politics but not necessarily populism. This raises a very important question: "was Mahatma Gandhi a populist or a Hindu populist?" Most scholars working on populism in India have rejected this notion. Jaffrelot and Tillin (2017) take a broad overview of populism in India but start it from the 1960s. Gianolla (2020) contrasts Gandhian politics with (demagogic) populism and argues that Gandhi's intercultural democratic discourse can help save liberal democracy from the threat of populism. Kumar (2019) also does not consider Gandhi a populist:

Democracy and populism are cousins. A charismatic leader mesmerises the electorate, strikes an emotional chord and blurs the distinction between the leader and the led. However, a charismatic-popular-populist pitch doesn't automatically transcend into populism. It requires demagoguery wherein hitherto suppressed but popular desires get articulated by a mesmeriser who emerges as the saviour. Both Mahatma Gandhi and Jawaharlal Nehru were charismatic but not populist as they assumed a guiding role vis-à-vis the people rather than getting subsumed by their worldview. Gandhi didn't hesitate to withdraw the non-cooperation movement in the aftermath of Chauri Chaura when it gained momentum, and Nehru stood for secularism and scientific rationality in the midst of Partition's mass frenzy. The popular and the populist can be perfect strangers or bedfellows, and their transition into populism lies in a social, political and electoral mix.

Although there seems to be broad agreement on Gandhi not subscribing to populism, there are certain aspects of populism that one observes in Gandhian politics. There was certainly a division between a small corrupt colonial elite ruling millions of righteous Indian masses. There was also a temporal dimension when this colonial elite would be defeated, and Swaraj or self-rule would be achieved which would be much better than the past. Of course, Gandhian Swaraj was a much broader concept than emancipation from British colonial rule. There was also a glorious, imagined past when life was ideal in ancient India. The Ramrajya (the rule of ancient major Hindu deity Lord Ram) was described by Gandhi in 1946 as "Kingdom of Heaven on Earth" and there was a desire to achieve something close to Ramrajya in post-independence India (Gandhi 2021).

Furthermore, while Gandhi believed and proposed equality of all religions in the future Indian state and encouraged a syncretic brand of Hinduism, he established and lived in ashrams, practiced yoga, dressed as a Hindu yogi, spoke as a Hindu monk and "articulated his views in a thoroughly Hindu style" (Jaffrelot 2007). Not surprisingly, there were Indians, primarily a large section of the Muslim community, who did not accept Gandhi's philosophy and politics. Accepting Gandhian populism that was based on ancient Hindu history and Hinduism would make it easier to explain the current success of Modi's Hindutva populism. However, there is one major difference between populism in general and Modi's populism in particular, on one hand, and Gandhi's Hindu populist politics; Gandhi's (elite or otherwise) enemies were not evil and Gandhian masses were not wholly innocent and pure. In Gandhi's worldview, non-violence was the ideal and there was no place for military trainings to defeat or defend against enemies. This was contrary to Hindu nationalists' kshatriya model, which prioritized vigor, militancy and domination (Andersen and Damle 1987, pp. 26-29). A large part of Gandhian philosophy was about self-control and subjugating one's own demons, which distinguishes it from populism in that the focus is almost wholly on the externality of evil. The following two quotes highlight the difference: 
I compare nirvana to Ramarajya or the Kingdom of Heaven on earth ... . The withdrawal of British power does not mean Ramarajya. How can it happen when we have all along been nursing violence in our hearts under the garb of non-violence?

If you want to see God in the form of Ramarajya, the first requisite is self-introspection. You have to magnify your own faults a thousand fold and shut your eyes to the faults of your neighbours. That is the only way to real progress.

The Manichean purity-impurity or morality-corruption distinction that is a feature of populism worldwide is clearly absent in Gandhi's politics. Another thing that distinguished Gandhi from populist leaders is his support for strong party institutions (Congress) and a parallel leadership (Jawaharlal Nehru) (Subramanian 2007). If Gandhi was not Hindu populist, he was certainly not Hindu nationalist. The major proponent of Hindu nationalism was V. D. Savarkar and his party, Hindu Mahasabha.

\section{Two Distinctions: Hindu Nationalism (Hindutva) vs. Hindu Populism and Populist Political Leaders vs. Populist Parties}

Hindu nationalism started to become popular in the late 19th century. It came out of the Hindu revivalist movements which tried to "modernize," unite and Semitize Hinduism. For these Hindu revivalist movements, the British were a source of both envy and threat. Brahmo Samaj and Arya Samaj are two of the most famous revivalist movements. These movements and developments created a Hindu consciousness which later became the basis of Hindu nationalism. The first ideologue of Hindu nationalism was V. D. Savarkar who wrote the book Hindutva: Who is a Hindu? in the early 1920s and associated Hindutva with not only religion but also with land, culture and language (Hindu, Hindi, Hindustan). He argued Hindu is the one who considers India as the land of his forefathers (pitribhumi) as well as his holy land (punyabhumi). Savarkar was a nationalist but there is debate whether his politics in the Hindu Mahasabha party can be called populist or not. Savarkar was certainly rousing a large majority of people against the corrupt elite, but his prime target changed depending on the time, from British, the Congress, to Muslims. Moreover, as far as strategy and style were concerned, he was not a populist leader, trying to lead an unorganized mass against the enemy using dirty rhetoric and bad manners (Visana 2020; Tharoor 2018, pp. 40-50). Similarly, his party Hindu Mahasabha cannot be called a populist party as it was not anti-elite. It was much more pro-British than Congress and relied for support on Hindu aristocracy, gentry and business elite, and had urban, high caste roots, similar to the pre-Gandhian Congress (Bapu 2013, pp. 26-43). So, Hindu Mahasabha was Hindu nationalist but not Hindu populist. This difference between rightwing nationalism and rightwing populism is important to keep in mind.

Although numerous rightwing populist parties are nationalist and a few nationalist parties have become populist, this does not mean that nationalist and populism are the same or always exist together. Rightwing nationalism has been growing since the 1970s. Israel had thirty years of leftwing governments before it had its first rightwing nationalist government in the late 1970s. However, since then, Israel has steadily moved rightward and this rightwing shift has helped make Benjamin Netanyahu the longest serving prime minister of Israel, without being populist. There were less remarkable rightwing shifts in both the US and British politics in the late 1970s and early 1980s. Populism in the US and Europe is a comparatively new phenomenon and with the rise of rightwing populism, there is also a less consequential rise in leftwing populism. Former President Trump was a rightwing nationalist populist but he was not the first rightwing nationalist president, and the Republican Party had long espoused rightwing nationalism. Almost every rightwing populist is a nationalist, but every rightwing nationalist is not a populist.

Keeping in view the above, while discussing the rise of Narendra Modi there is a tendency to extend Modi populism to the BJP early days in the 1980s or even to Hindu nationalists before India independence. As discussed above, Hindu nationalism has existed since the start of the 20th century. Hindu sabhas were formed and later many joined to form 
the first Hindutva or Hindu nationalist party. Now, one can argue that Hindu Mahasabha was also populist but just because Modi was populist, all Hindu nationalist parties cannot be painted populist. If one has to demonstrate the link between Hinduism and populism since the early 20th century, then one has to define populism, select a measuring scale and show the existence of populism. Modi populism is even insufficient to declare the BJP populist before Modi's rise. In fact, some scholars have argued that the BJP before Modi was not populist. The anti-elitism was missing before 2013. Plagemann and Destradi (2019) argue that Hindutva, although itself fuzzy, is the core and "thick" part of the BJP ideology and has defined the BJP during its whole life. In contrast, (Modi's) populism is the "thin" ideology and is a recent addition to BJP's repertoire. It may or may not survive Modi. This raises many questions. Was the BJP populist in 1984 or 1994 or even in 2004 under Vajpayee and Advani? There are no rigorous studies to decide one way or the other.

\section{Populist Political Parties and Populist Leaders}

The distinction between populist leaders and populist political parties is critical. Generally, populism is associated with larger-than-life leaders, such as Trump, Erdogan, Bolsonaro, Duterte, etc. However, it is possible that whole political parties are populist while their leaders are not, or vice versa. Populist leaders and populist parties both rise when the political system is in crisis. It can be in a long-term crisis extending numerous decades, with no history of ever known long-term stability, or it can be a crisis of an established political system. Since the 1950s, many populist leaders in Africa and Latin America rose after decades of instability or after the end of colonial rule. Gamal Abdel Nasser of Egypt and Juan Peron of Argentina are examples of such populist leadership. More recently, populism is associated with the crisis of well-established political and party systems in consolidated democracies (see the Figure 1). There is a rejection of once favored political parties and constitutional arrangements. It is the loss of legitimacy of the existing political parties, not only of political leaders, that has also resulted in the rise in populists (Roberts 2017).
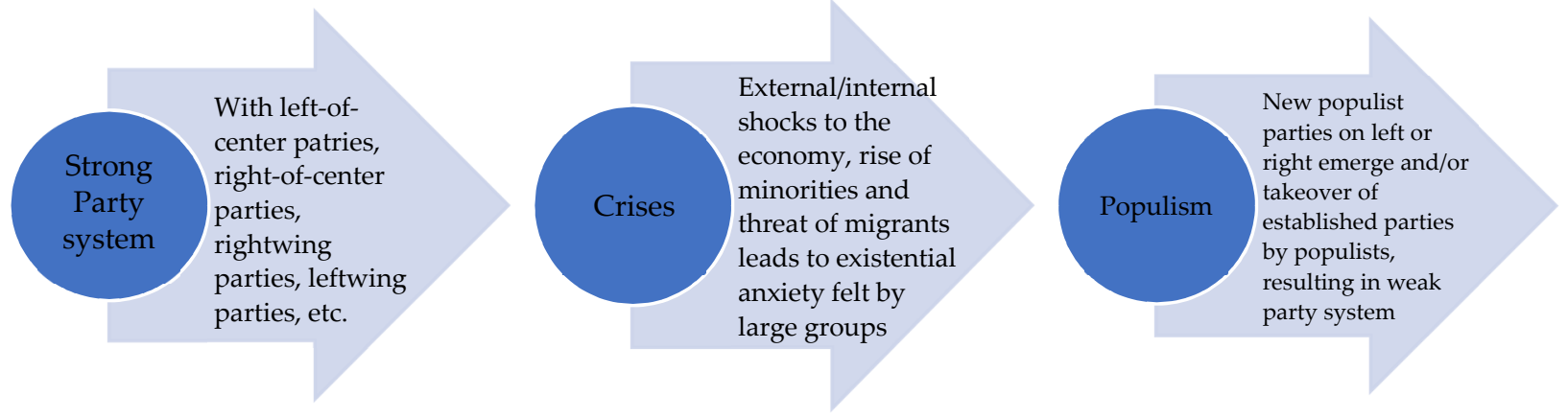

Figure 1. Loss of legitimacy and rise of populism.

\section{Hindutva Organizations: Rashtriya Swayamsevak Sangh (RSS) and Bhartiya Jana Sangh (BJS)}

The RSS was and is the premier Hindu nationalist organization in India. The focus of RSS is on the unity and character building of Hindus, who (allegedly) have become soft and disorganized under colonial rule. The primary threats for the RSS to Hinduism were evangelical faiths, Islam and Christianity. The RSS promotes a belief system where Hindus are considered weak because of lack of understanding and/or observance of dharma. While deterioration of contemporary Hindu society is lamented, the RSS does not consider it of recent origin. The loss of vitality and strength of Hindu society is associated with Muslim invasions and control of India more than a thousand years ago (Andersen and Damle 1987, p. 72). It was established by K. B. Hedgewar in 1925. Hedgewar and M. S. Golwalkar, who became the RSS's leader in 1940, were both organization men. They had the Manichean view of a virtuous mass fighting against a corrupt elite but, again, 
their strategy and style were not populist. Rather than eliminating the intermediaries and leading a group of people that is totally and personally devoted to them, they established RSS as a hierarchical organization with branches (shakhas) in states, towns and cities across the nation. They were not populists; they were organization men (Yilmaz et al. 2021; Jaffrelot 2007). As is the case with the BJP, the RSS also grew rapidly in the 1990s and it is currently one of the largest and most active NGOs in the world, with nearly 57,000 shakhas or daily meetings at thousands of meeting points in India and abroad (Andersen and Damle 2019, p. xi).

The BJS was established as the political arm of RSS when, after being banned after Gandhi's assassination, RSS realized that it could not remain completely aloof from politics and needed protection in case a situation such as 1948 arose again. Another reason was to give an opening to those RSS activists who were interested in directly taking part in politics (Andersen and Damle 1987, p. 112). The BJP's policies were aligned to RSS and revolve around Hindutva. Its leadership, as with the RSS leadership, cannot be called populist because party workers identified more with the party than with a specific leader, although some of them were popular. Although BJS President Deen Dayal Upadhyaya was one of the most significant ideologues of the Hindutva movement and President Atal Bihari Vajpayee was a very popular politician (later prime minister), their style and strategy was not populist.

\section{Methods: Identifying Hindu Nationalist and Populist Political Parties}

There are now scores of articles focusing on PM Modi's successful marketing of a combination of Hinduism, nationalism and populism. There is also a vast literature on the rise of Hindu nationalism (Hindutva) since the mid-1980s. However, there are few, if any, articles highlighting and comparing the populism of major rightwing Hindu nationalist parties. This article intends to fill this gap. It will focus on the Hindu Mahasabha, BJS and BJP. The selection of these three Hindutva parties is based on their success at the national level. Hindu Mahasabha, BJS and BJP are by far the most successful parties in Indian national elections. The selection of Hindu Mahasabha and the BJS manifestos is based on availability. However, the four BJP manifestos were chosen to represent each decade of the party's life. The first national election manifesto (1984) and most recent one (2019) were chosen to get the full spectrum of change, if any, in BJP's ideals and promises.

The research method chosen for this study is qualitative content analysis. All seven party manifestos will be thoroughly studied, rigorously examined and statements / sentences related to various aspects of Hindu nationalism and Hindu populism will be identified and reproduced in the paper. The cultural and other aspects related to nationalism and populism chosen are primarily based on a PEW research study on European populist parties as explained below. Once data is collected, it will be analyzed and conclusions drawn regarding whether (and when) the three parties were becoming more/less Hindutva nationalist and/or populist. Since it is a quantitative study, the approach is flexible, not rigid, and specific words or phrases are not counted. The approach is analytic as various aspects of nationalism and populism do not appear in the same way in 2019 as they appeared in the 1960 s or the 1980 s.

It can be argued that instead of comparing Hindu Mahasabha and BJS manifestos with BJP manifestos, it would have been better to compare BJP manifestos for the last forty years. Forty years is a sufficiently long period for analysis. The argument is reasonable, however, all three Hindutva parties' manifestos are compared to highlight and analyze the development of Hindu nationalism and populism political rhetoric and promises. It is true that the BJP is the most significant and remarkable part of the Hindutva story, but it is not the only part and to understand this exceptional part, one needs to examine its past.

Scholars have used several different ways to measure (rightwing) populism in political parties. In this article, a modified (and also less rigorous) version of PEW research and the Inglehart and Norris method of identifying European populist parties would be employed. They focused on the anti-elitism and cultural views of populist political parties 
and developed a populist party scale using the 2014 Chapel Hill Expert Survey (CHES) data for classification. The CHES scale is based on expert ratings of the party which are aggregated to decide whether a party is populist or not and what is its cultural orientation. Experts give their views on a scale of 1 to 10 regarding party positions regarding the following cultural issues: (1) support for traditional social values, (2) opposition to liberal lifestyles, (3) promotion of nationalism, (4) favorable toward tough law and order, (5) favorable toward assimilation for immigrants and asylum seekers, (6) support for restrictive immigration policies, (7) opposition to more rights for ethnic minorities, (8) support for religious principles in politics and (9) support for rural interests. To measure anti-elitism, experts' view on direct vs. representative democracy and salience of these views were analyzed (Pew Research Center 2019). For this article, most of the above criteria are used but instead of expert opinions, party manifestos are used to ascertain the populism and cultural orientation of the party. There has been a strong tradition in the academic literature on political parties using manifestos to gauge party positions (Kirchner 1988; Pennings 2006; Libbrecht et al. 2009). Some may argue that manifestos do not reflect actual party positions but there is no sure way of measuring a party's intent. One can use leadership speeches, expert or voter surveys or analyze previous policies, but each measure has its own shortcomings.

Anti-elitism and a clear break from the past are two constitutive elements of populism. Therefore, two additional criteria, disapproval of the constitution and changes proposed in it and the usage of the word "new" have been added, based on literature reviewed on populism. Anti-elitism is the most important characteristic of populism. Populist leaders and parties also regularly emphasize their "newness" and project themselves as a break from the past. Some of these parties are new but those which have existed for a long time also promote or exaggerate their novelty. Manifestos, however, are full of promises, with the word "new" freely thrown around. It can be "new" hospitals, schools, roads, laws, policies, airports, etc. So, in this article, not only will the number of times "new" is used be measured but the context will also be analyzed. The assumption is that populist party manifestos will use "new" in a much more expansive way, such as "new India," "new era," "new polity," etc. The third criteria to measure populism is how many times the name of the party leader is mentioned or if a picture of the leader is printed in the manifesto. Personalization and de-institutionalization of politics is a key characteristic of populism. Under populism, party campaigns shift from party ideology to charismatic populist leader's capabilities. Loyalties are also transferred to the leader instead of the party (Liddiard 2019; Baudner 2018). Donald Trump, Tayyip Erdogan, Jair Bolsonaro, Imran Khan, Victor Orban and Matteo Salvini are examples of populist leaders who either created new parties or molded established parties in their own image. Therefore, personalization of politics and promotion of the leader is closely linked with populism.

\section{Hindu Populism and Hindu Nationalism of Rightwing Parties: Analysis of Their Manifestos}

The following analysis is based on the manifestos of rightwing Hindutva parties for a period of more than fifty years. As explained above, all major rightwing parties, Hindu Mahasabha, BJS and BJP, have been included. As BJP has been the most successful and transformed over the forty years of its existence, four of its manifestos $(1984,1996,2009$ and 2019) have been analyzed. Direct quotes from party manifestos have been included to show the rightwing nationalism and populism of these parties. The first nine criteria demonstrate Hindu nationalism while the last three highlight Hindu populism. Based on the analysis of manifestos, while Hindu nationalism is decreasing, Hindu populism is increasing in Indian rightwing parties.

\section{Analysis of Party Manifestos}

Investigating the Hindutva (rightwing cultural bent) of these parties, one can initially detect a decrease in blatant Hindu nationalism in these manifestos. Hindu Mahasabha's 1967 manifesto (Table 1) unapologetically calls for "a Hindu state based on Hindu Culture 
and traditions" and wanted to Hinduize politics and militarize Hindus. Such statements were not found in other manifestos examined in this article. For instance, the BJS's 1967 manifesto (Table 2) presents values associated with Hindu culture, not as Hindu values but as ancient values of India as a whole. The BJS's hope is to lead India's centuries old struggle ("The nation's centuries old struggle for Swadesh, Swadhrarma, and Swatantra cannot thus be allowed to be frustrated under Swaraj"). Cow is not a religious point of honor but a "national point of honour." This trend continues in BJS's 1971 manifesto (Table 3) where Hindu supremacist sentiments or the desire of a Hindu rashtra are absent. Instead, there is talk of "cultural heritage," swabasha and "indianization." One can still find sentences affirming Hindutva, such as a desire of protection of cow family, hatred for Christian missionaries and Muslim League and proposal to make Hindi lingua franca.

Analyzing BJP's manifestos, the 1984 manifesto (Table 4) seems to be the lowest point as far as Hindutva is concerned. In the manifesto, the BJP rejected the theocratic state and focus on tradition and cultural values is limited. The BJP pledges to introduce not national, ancient, cultural or traditional instruction, but nondenominational moral instruction. Except for the banning of cow slaughter, there is not much linked to Hindutva. Both desire for a uniform civil code and restrictions on Christian missionaries are missing. According to Andersen and Damle (1987, p. 143), during the early 1980s, the BJP leadership tried to present itself as a secular alternative to the Congress so, unsurprisingly, most of the demands associated with Hindutva were absent.

Table 1. Hindu nationalism and populism in Hindu Mahasabha based on 1967 manifesto (Hindu Mahasabha 1966).

\begin{tabular}{|c|c|c|}
\hline No. & Criteria & Hindu Mahasabha Election Manifesto, 1967 \\
\hline 1 & $\begin{array}{l}\text { Support for traditional social } \\
\text { values }\end{array}$ & $\begin{array}{l}\text { Start of the manifesto: "Hindustan is the land of the Hindus from time immemorial } \\
\text {... The Hindu Mahasabha believes that Hindus have a right to live in peace as } \\
\text { Hindus, to legislate, to rule, to govern themselves in accordance with Hindu genius } \\
\text { and ideals and establish ... a Hindu state based on Hindu Culture and traditions so } \\
\text { that Hindu ideology and way of life should have a Homeland of its own." } \\
\text { "The Hindu Mahasabha stands for social and economic justice with its moorings in the } \\
\text { moral and spiritual past of this sacred land." }\end{array}$ \\
\hline 2 & Opposition to liberal lifestyles & $\begin{array}{l}\text { "The Hindu Mahasabha aspires to create a social order based on 'Hindutva' which } \\
\text { advocates class-coordination and social-consciousness, as against class-conflict and } \\
\text { individual consciousness ... progammes of the Mahasabha are basically based on the } \\
\text { aforesaid principles, which suit the genius if the people and on which the Hindu } \\
\text { nation and civilization have survived for thousands of years." } \\
\text { "A social and economic order based on Hindu way of life, can only stabilize the } \\
\text { present imbalanced structure of Bharat, -nay of the world." }\end{array}$ \\
\hline 3 & Promotion of nationalism & $\begin{array}{l}\text { Title of a section: "Curbs on De-nationalising Activities" } \\
\text { Last sentence of manifesto: "It [Hindu Mahasabha] has every hope and confidence } \\
\text { that the people of Hindustan will give an opportunity to a large number of Hindu } \\
\text { Mahasabha candidates to represent them in the Central and State Legislatures so that } \\
\text { the anti-national trend in our politics might be checked in good time and a strong and } \\
\text { united Hindustan might emerge at an early date. Vande Matarm." }\end{array}$ \\
\hline 4 & $\begin{array}{l}\text { Favorable toward tough law } \\
\text { and order }\end{array}$ & $\begin{array}{l}\text { "Industrial and labour laws calculated to sow seeds of dissension between the } \\
\text { employer and the employed should be suitably repealed and conciliation boards } \\
\text { should be encouraged instead of resorting to strikes, lock-outs etc." }\end{array}$ \\
\hline 5 & $\begin{array}{l}\text { Favorable toward assimilation } \\
\text { for immigrants and } \\
\text { asylum seekers }\end{array}$ & $\begin{array}{c}\text { "The Hindu Mahasabha organized shelter and relief to Hindu refugees from Pakistan } \\
\text { and arranged for their rehabilitation." }\end{array}$ \\
\hline 6 & $\begin{array}{l}\text { Support for restrictive } \\
\text { immigration policies }\end{array}$ & $\begin{array}{l}\text { "The Assam Hindu Mahasabha repeatedly drew the attention of the government } \\
\text { towards mass infiltration and concentration of Pakistani Muslims in Assam." }\end{array}$ \\
\hline 7 & $\begin{array}{l}\text { Opposition to more rights for } \\
\text { ethnic minorities }\end{array}$ & $\begin{array}{l}\text { No mention of ethnic minorities. Their existence is not even acknowledged. } \\
\text { "Hindu Mahasabha stands for Hindu, Hindi, and Hindustan." }\end{array}$ \\
\hline
\end{tabular}


Table 1. Cont.

\begin{tabular}{cc}
\hline No. & Criteria \\
\hline & \\
& \\
& \\
8 & Support for religious \\
& principles in politics
\end{tabular}
principles in politics Support for rural interests

10 Disapproval of or changes proposed in the constitution

Hindu Mahasabha Election Manifesto, 1967

Title of a section: "Hinduise Politics and Militarise Hindudom"

"country can only be saved ... if the country's politics is "Hinduised."

"Befriending and fraternizing all neighbouring Hindu countries"

"The Hindu Mahasabha considers it absolutely essential to amend the present Constitution ... to ban the slaughter of cows, calves, bulls, and bullocks of every age and condition, under all circumstances."

Title of a section: "Revision of Anti-Hindu laws"

"The Hindu Mahasabha stands for imposition of effective ban on the activities of foreign Christian Missionaries who are busy converting tribal and other people...with the ultimate object of denationalizing them and reducing the Hindu majority in the country into a minority ... so that Hindustan might cease to be a Hindu homeland."

"Conversion from Hinduism should be altogether banned."

"The Hindu Mahasabha stands for resisting all attempts made to dislodge

'Sanskrit-Nistha' Hindi from the place it has been given in the Constitution as a Union Language."

"The Hindu Mahasabha stands for the restoration of all Hindu temples ... which are now in the illegal possession of Moslems."

The definition of a Hindu according to Hindu Mahasabha as given in the manifesto:

"One who regards this land of Bharat from Indus to the Seas, as his fatherland as well as holy land, is a Hindu."

"The Hindu Mahasabha is further of the opinion that the only method of saving the life and honour of the Hindu minorities in Pakistan is to bring about an exchange of population between the Hindu minorities in Pakistan and Muslims in Hindustan."

A whole section focused on agriculture policy. Some of the steps were:

"Arrange adequate supply of good seeds, fertilizers, and mechanized implements and latest scientific and technological knowledge for agricultural operations."

"Encourage the co-operative movement."

"Hindu Mahasabha is of the considered opinion that the present Constitution is altogether unsuited to the genious (sic) of the people of Hindustan ... and there is hardly anything "Indian" about it ... Hindu Mahasabha therefore stands for recasting the Constitution of the country to bring it in consonance with the tradition and culture of the Hindus to make it a truly democratic Hindu State."

"The Hindu Mahasabha demands that Article 370 of the Constitution should be forthwith abrogated."

\begin{tabular}{|c|c|c|}
\hline 11 & $\begin{array}{l}\text { New polity, new era, etc. } \\
\text { (demonstrating a break from } \\
\text { the present/immediate past) }\end{array}$ & $\begin{array}{l}\text { Although it does hint at a break from the past, there is only one instance of usage of } \\
\text { the word "new" and that is also not related to imagining of a new India or new era: } \\
\text { "Even the new fourth Five Year Plan has failed" }\end{array}$ \\
\hline 12 & $\begin{array}{l}\text { Name or picture of the } \\
\text { party leader }\end{array}$ & $\begin{array}{l}\text { No mention or picture of current leadership. However, recently deceased V.D. } \\
\text { Savarkar (1883-1966) is mentioned many times. }\end{array}$ \\
\hline
\end{tabular}

Table 2. Hindu nationalism and populism in Bharatiya Jana Sangh based on 1967 manifesto (BJS 1967).

\begin{tabular}{|c|c|c|}
\hline No. & Criteria & BJS Election Manifesto, 1967 \\
\hline 1 & $\begin{array}{l}\text { Support for traditional } \\
\text { social values }\end{array}$ & $\begin{array}{l}\text { "The nation's centuries old struggle for Swadesh, Swadhrarma, and Swatantra cannot } \\
\text { thus be allowed to be frustrated under Swaraj." } \\
\text { "By neglecting India's basic values in regard to character and righteous conduct... } \\
\text { this Government has created a climate in which corruption is having a field day." }\end{array}$ \\
\hline 2 & Opposition to liberal lifestyles & $\begin{array}{c}\text { "Bharatiya Jana Sangh will reform the system and content of education so as to bring } \\
\text { it in tune with modern attainments and national values." } \\
\text { "Bharatiya Jana Sangh regards drinking as a social evil which needs to be } \\
\text { seriously tackled." }\end{array}$ \\
\hline
\end{tabular}


Table 2. Cont.

\begin{tabular}{|c|c|c|}
\hline No. & Criteria & BJS Election Manifesto, 1967 \\
\hline 3 & Promotion of nationalism & $\begin{array}{c}\text { Support for one nation, one people. } \\
\text { "It [Congress] has surrendered the areas of Pakistan-occupied Kashmir that our } \\
\text { jawans had valiantly liberated." } \\
\text { "Soon thereafter came the historic march on Lahore which stirred the nation to its } \\
\text { depths and resulted in an upsurge in united national endeavour, unprecedented in the } \\
\text { annals of free India." } \\
\text { "The nation's stocks soared high, and the people experienced a sense of confidence." } \\
\text { "Both Communist China and Pakistan are in illegal occupation of large areas of India } \\
\text { territory. The Congress Government has never cared to free them." } \\
\text { "The needs of defence were never considered by the planners." }\end{array}$ \\
\hline 4 & $\begin{array}{l}\text { Favorable toward tough law } \\
\text { and order }\end{array}$ & $\begin{array}{c}\text { "Bharatiya Jana Sangh is not bound by any 'ism' so far as the question of defending } \\
\text { the integrity of motherland, maintenance of law and order and providing the } \\
\text { minimum needs of the people are concerned." } \\
\text { "There are forces in the country which are working as fifth columnists of the enemies } \\
\text { and have been threatening India's integrity and sovereignty ... Bharatiya Jana Sangh } \\
\text { will enact a law of treason and deal with these anti-national elements under } \\
\text { provisions of this law." }\end{array}$ \\
\hline 5 & $\begin{array}{l}\text { Favorable toward assimilation } \\
\text { for immigrants and } \\
\text { asylum seekers }\end{array}$ & $\begin{array}{l}\text { "There has been a continuous exodus of non-Muslims, particularly Hindus, from } \\
\text { Pakistan ... It is the Government's responsibility to rehabilitate and } \\
\text { compensate them." } \\
\text { "Citizenship rights will be conferred in the course of rehabilitation." }\end{array}$ \\
\hline 6 & $\begin{array}{l}\text { Support for restrictive } \\
\text { immigration policies }\end{array}$ & \\
\hline 7 & $\begin{array}{l}\text { Opposition to more rights for } \\
\text { ethnic minorities }\end{array}$ & $\begin{array}{l}\text { No mention of ethnic minorities. Their existence is not even acknowledged. } \\
\text { "Hindi medium institutions will be established in all parts of the country." }\end{array}$ \\
\hline 8 & $\begin{array}{l}\text { Support for religious } \\
\text { principles in politics }\end{array}$ & $\begin{array}{c}\text { "The cow is our national point of honour ... Bharatiya Jana Sangh will amend the } \\
\text { constitution and impose a legal ban on the slaughter of the cow and its progeny ... ; } \\
\text { implement uniform civil law" } \\
\text { "Sanskrit will be declared as country's National Language." } \\
\text { "Restrictions will be imposed on the activities of foreign missionaries." }\end{array}$ \\
\hline 9 & Support for rural interests & $\begin{array}{c}\text { "Bharatiya Jana Sangh gives first priority to agriculture." } \\
\text { "They [farmers] will be provided fertilizers, seeds, bullocks and implements at } \\
\text { subsidized rates." } \\
\text { "Bharatiya Jana Sangh will make a statutory provision for the State Bank and other } \\
\text { commercial banks to open branches in the villages so that credit needs of the farmers } \\
\text { are adequately met at low interest." } \\
\text { "Jana Sangh will arrange for the insurance of farm produce." }\end{array}$ \\
\hline 10 & $\begin{array}{l}\text { Disapproval of or changes } \\
\text { proposed in the constitution }\end{array}$ & $\begin{array}{c}\text { "The present constitution does not represent the country's basic unity, BJS will amend } \\
\text { it and declare India a unitary state." } \\
\text { "In order to bring the State of Jammu and Kashmir at par with other provinces ... } \\
\text { Jana Sangh will delete Article 370." }\end{array}$ \\
\hline 11 & $\begin{array}{l}\text { New polity, new era, etc. } \\
\text { (demonstrating a break from } \\
\text { the present/immediate past) }\end{array}$ & $\begin{array}{l}\text { The word "new" was used six times. Following instances demonstrate } \\
\text { populist aspects: } \\
\text { First line of the manifesto: "For the people of India, eager to herald a new era" } \\
\text { Last line of the manifesto: "Let us exert to bring about a democratic revolution } \\
\text { through the fourth general election and give the country a new direction." }\end{array}$ \\
\hline 12 & $\begin{array}{l}\text { Name or picture of the } \\
\text { party leader }\end{array}$ & There was no mention or picture of Deen Dayal Upadhyaya, the BJS president. \\
\hline
\end{tabular}


Table 3. Hindu nationalism and populism in Bharatiya Jana Sangh based on 1971 manifesto (BJS 1971).

\begin{tabular}{|c|c|c|}
\hline No. & Criteria & BJS Election Manifesto, 1971 \\
\hline 1 & $\begin{array}{l}\text { Support for traditional } \\
\text { social values }\end{array}$ & $\begin{array}{c}\text { "We [Jana Sangh] will give a positive, patriotic and moral content to education to inculcate in our } \\
\text { children deep love of our country, our people and our cultural heritage. To this end, we will } \\
\text { revise the text books." } \\
\text { "Jana Sangh will reform the educational system so that it can serve simultaneously to strengthen } \\
\text { national values and fulfil the needs of modern India." }\end{array}$ \\
\hline 2 & $\begin{array}{c}\text { Opposition to liberal } \\
\text { lifestyles }\end{array}$ & $\begin{array}{l}\text { "Jana Sangh stands for equal opportunities for women. It will encourage their employment to the } \\
\text { types of jobs for which they have special aptitude ... and arrange for more rational distribution } \\
\text { of the female labour force so as to reduce competition between men and women." } \\
\text { "We [Jana Sangh] will ... progressively diminish the consumption of alcoholic drinks. }\end{array}$ \\
\hline
\end{tabular}

(Article 47)."

"Jana Sangh regards India as one nation, and all Indians as one people."

"Never before has a Prime Minister in a democracy entered into such open collusion with anti-national and anti-democratic forces."

$3 \begin{gathered}\text { Promotion of } \\ \text { nationalism }\end{gathered}$

"They are clear omens that the nation is being dragged to the brink of disaster."

BJS appeals to the people to reject the government "and install in its place an alternative government unequivocally committed to nationalism, democracy and building up of an egalitarian society."

"Never before has a Government had such a dismal record of unmitigated failure in the maintenance of law and order."

$4 \quad$ Favorable toward tough law and order
"It has been 10 months that West Bengal has been under President's Rule. But the law and order situation has shown no improvement."

"In this election, the options before the voter are: democracy or totalitarianism; peaceful change or violent upheaval; orderly progress or anarchy; Rule of Law or the law of the jungle." (capitalization of first letters of "rule" and "law" from the original)

"Jana Sangh will expedite the rehabilitation of refugees already here."

Favorable toward assimilation for immigrants and asylum seekers
"The diversity of castes, creeds, languages, and provinces only lend beauty and splendour to the unity of our national life, which is so assimilative that even those who came as invaders were absorbed in it."

Title of a section: "National Integration Through Indianization"

\begin{tabular}{cc}
\hline 6 & $\begin{array}{c}\text { Support for restrictive } \\
\text { immigration policies }\end{array}$ \\
\hline 7 & $\begin{array}{c}\text { Opposition to more } \\
\text { rights for ethnic } \\
\text { minorities }\end{array}$ \\
\hline
\end{tabular}

8
Support for religious principles in politics

"We shall stop all infiltration from Pakistan and pack off old infiltrators."

No mention of ethnic minorities. Their existence is not even acknowledged.

"Swaarajya is incomplete without Swabhasha ... Jana Sangh will develop Hindi as the link language over the next five years."

“We [Jana Sangh] will implement the forgotten Directive Principles of the Constitution and ... protect the cow family (Article 48)."

Government has supported communalists and "promoted the ominous revival of the Muslim League."

"We [Jana Sangh] shall impose restrictions on the activities of foreign missionaries." $9 \begin{aligned} & \text { Support for rural } \\ & \text { interests }\end{aligned}$

Disapproval of or

10 changes proposed in the constitution
"Our biggest industry is agriculture"

"It [Jana Sangh] will lower irrigation and electricity charges, introduce crop and cattle insurance, and promote cattle breeding and animal husbandry."

"Jana Sangh does not regard the Constitution as a static document ... Care, however, was taken to ensure the essential fabric of the Constitution-which the Jana Sangh thinks is basically sound-is not tampered with levity."

"It feels, however, that the time has come when a 'Commission on Constitution' should be created to review the working of the Constitution in the light of the experience of past two decades."

New polity, new era, etc. (demonstrating a break from the present/immediate past)

\section{The word "new" was used four times.}

Following instances demonstrate populist aspects:

"Jana Sangh believes that the emergence of a brave new India would remain a dream so long as the basic postulates are not spelt out in clear terms."

Heading of a section: "A new deal with earners." 
Table 4. Hindu nationalism and populism in Bharatiya Janata Party based on 1984 manifesto (BJP 1984).

\begin{tabular}{|c|c|c|}
\hline No. & Criteria & BJP Election Manifesto, 1984 \\
\hline 1 & $\begin{array}{l}\text { Support for traditional social } \\
\text { values }\end{array}$ & $\begin{array}{l}\text { "BJP believes in the sanctity of life. It appreciates small happy families." } \\
\text { "It is also conscious of the damage that is being caused to the moral and social fibre of } \\
\text { the people by their exposure to violence and vulgarity in films." }\end{array}$ \\
\hline 2 & Opposition to liberal lifestyles & $\begin{array}{c}\text { "Introduce compulsory moral instruction, that will be } \\
\text { nondenominational but character-building." }\end{array}$ \\
\hline 3 & Promotion of nationalism & $\begin{array}{l}\text { The title of the BJP programme was "National Politics, National Unity and } \\
\text { Positive Secularism." } \\
\text { The manifesto called "National integrity, unity, and cohesion are the paramount need } \\
\text { of the hour; the reestablishment of national consensus a primary task." } \\
\text { "There can be no compromise with those who talk of Khalistan." } \\
\text { "Make some school texts common throughout the country for national integration" }\end{array}$ \\
\hline 4 & $\begin{array}{l}\text { Favorable toward tough law } \\
\text { and order }\end{array}$ & $\begin{array}{c}\text { "The BJP views with alarm the rise of social violence in the country. This includes } \\
\text { communal violence, atrocities on Harijans and tribals, and criminal assaults on } \\
\text { women. It is committed to the security of life, limb, property and honour of } \\
\text { all citizens." } \\
\text { "Separatism and terrorism will be sternly dealt with." }\end{array}$ \\
\hline
\end{tabular}

Favorable toward assimilation

5 for immigrants and asylum seekers

\begin{tabular}{|c|c|c|}
\hline 6 & $\begin{array}{l}\text { Support for restrictive } \\
\text { immigration policies }\end{array}$ & $\begin{array}{l}\text { "The BJP will take all effective steps to prevent further illegal immigration. For this } \\
\text { purpose it will work towards joint, cooperative effort by all the concerned adjoining } \\
\text { states like Tripura, West Bengal and Bihar." }\end{array}$ \\
\hline 7 & $\begin{array}{l}\text { Opposition to more rights for } \\
\text { ethnic minorities }\end{array}$ & No mention of ethnic minorities. Their existence is not even acknowledged. \\
\hline 8 & $\begin{array}{l}\text { Support for religious } \\
\text { principles in politics }\end{array}$ & $\begin{array}{l}\text { BJP categorically rejected the establishment of a theocratic state in the manifesto. } \\
\text { "The very idea of a theocratic state is alien to Indian political history." } \\
\text { "Cow slaughter will be banned." }\end{array}$ \\
\hline 9 & Support for rural interests & $\begin{array}{l}\text { "Agriculture is our biggest industry. It is the backbone of the economy. BJP will } \\
\text { encourage it in every way." }\end{array}$ \\
\hline 10 & $\begin{array}{l}\text { Disapproval of or changes } \\
\text { proposed in the constitution }\end{array}$ & $\begin{array}{l}\text { Two times a close relationship is shown towards the constitution: } \\
\text { "Ours is a democratic federal Constitution." } \\
\text { and } \\
\text { "... as visualised by our constitution makers." } \\
\text { The only constitutional amendment proposed is removal of Article } 370 \text {. }\end{array}$ \\
\hline 11 & $\begin{array}{l}\text { New polity, new era, etc. } \\
\text { (demonstrating a break from } \\
\text { the present/immediate past) }\end{array}$ & $\begin{array}{c}\text { The word "new" was used nine times. Following instances demonstrate } \\
\text { populist aspects: } \\
\text { The manifesto is titled "towards a new polity." } \\
\text { "The need of the hour is a new polity, a new government, a new leadership." } \\
\text { "Come, join us in our endeavour, to build a new India." }\end{array}$ \\
\hline 12 & $\begin{array}{l}\text { Name or picture of the party } \\
\text { leader* }\end{array}$ & $\begin{array}{l}\text { "Vajpayee" named only one in the manifesto: } \\
\text { "And its [BJP's] collective leadership, headed by the inimitable Atal Bihari Vajpayee is } \\
\text { the best and the brightest in the land." } \\
\text { *The title page could not be found so one or two pictures of Vajpayee might be printed } \\
\text { on the title page. }\end{array}$ \\
\hline
\end{tabular}

"Mindful of the national commitment of bonafide refugees in the region, the BJP will work continuously to protect their interests." 
studied, this manifesto is the most forceful in terms of its commitment to Hindutva. In terms of pledging allegiance to Hindutva, the 1996 manifesto is the most transparent of all the BJP manifestos analyzed in this article. Perhaps it had something to do with the Supreme Court's decision in 1996 that accepted that the term "Hindutva" was not communal or related specifically to strict Hindu practices but associated with "culture and ethos of people of India" (Mahapatra 2018).

Table 5. Hindu nationalism and populism in Bharatiya Janata Party based on 1996 manifesto (BJP 1996).

\begin{tabular}{|c|c|c|}
\hline No. & Criteria & BJP Election Manifesto, 1996 \\
\hline 1 & $\begin{array}{l}\text { Support for traditional social } \\
\text { values }\end{array}$ & $\begin{array}{l}\text { "Our Manifesto [is] based on the four concepts of Suraksha, Shuchita, Swadeshi and } \\
\text { Samrasata. Hindutva, or cultural nationalism, shall be the rainbow which will bridge } \\
\text { our present to our glorious past and pave the way for an equally glorious future; it } \\
\text { will guide the transition from Swarajya to Surajya." } \\
\text { "It [BJP] will redefine the concept of development to accommodate the Bharatiya way } \\
\text { of living, belief system and values to reach the ultimate goal of Bharatiyata." } \\
\text { "Promote Bharatiya classical music and performing arts through state support." }\end{array}$ \\
\hline 2 & Opposition to liberal lifestyles & $\begin{array}{l}\text { "Enact a law that will debar those with more than two children from holding elected } \\
\text { office, with } 1996 \text { as the cutoff year." } \\
\text { "The BJP will also introduce disincentives like limiting subsidized ration and } \\
\text { maternity benefits to two children with } 1996 \text { as the cut-off year." } \\
\text { "Amend the Prevention of Immoral Traffic Act to make clients as culpable as } \\
\text { commercial sex workers." } \\
\text { "Discourage indecent representation of women in advertisements and publications; } \\
\text { young minds. Sex and violence on the silver screen are beginning to gnaw at the } \\
\text { moorings of our cultural ethos." }\end{array}$ \\
\hline 3 & Promotion of nationalism & $\begin{array}{l}\text { "The BJP believes in one nation, one people, and one culture." } \\
\text { "Enact a law that will make registration of marriages with foreigners mandatory." }\end{array}$ \\
\hline 4 & $\begin{array}{l}\text { Favorable toward tough law } \\
\text { and order }\end{array}$ & $\begin{array}{c}\text { "Terrorism and challenges to the state will be met forthrightly; changes in law where } \\
\text { warranted will be brought about expeditiously; the approach will be firm but } \\
\text { always fair." } \\
\text { "Provide our security apparatus with a free hand to deal with terrorism." } \\
\text { "Legislate tough deterrent laws against terrorist and disruptive activities (TADA was } \\
\text { repealed to pander to vote bank politics) while safeguarding democratic rights." }\end{array}$ \\
\hline 5 & $\begin{array}{l}\text { Favorable toward assimilation } \\
\text { for immigrants and asylum } \\
\text { seekers }\end{array}$ & \\
\hline 6 & $\begin{array}{l}\text { Support for restrictive } \\
\text { immigration policies }\end{array}$ & $\begin{array}{l}\text { Two paragraphs and five action points on illegal immigration, which is called an } \\
\text { explosive issue, demographic invasion and a threat to security, in the manifesto. }\end{array}$ \\
\hline 7 & $\begin{array}{l}\text { Opposition to more rights for } \\
\text { ethnic minorities }\end{array}$ & No mention of ethnic minorities. Their existence is not even acknowledged. \\
\hline 8 & $\begin{array}{l}\text { Support for religious } \\
\text { principles in politics }\end{array}$ & $\begin{array}{l}\text { "Hindutva is a unifying principle which alone can preserve the unity and integrity of } \\
\text { our nation." } \\
\text { BJP will facilitate construction of a Ram Mandir "which will be a tribute to Bharat } \\
\text { Mata. This dream moves millions of people in our land; the concept of Rama lies at } \\
\text { the core of their consciousness." } \\
\text { BJP will "Impose a total ban on the slaughter of cows and cow progeny by amending } \\
\text { Article } 48 \text { of the Constitution to cover bulls and bullocks, and prohibit all trading } \\
\text { (state as well as private) in the slaughter of cows and cow progeny." }\end{array}$ \\
\hline 9 & Support for rural interests & $\begin{array}{l}\text { Seven page chapter, titled "Our Villages, Our Farmers, Our Poor," tackling almost all } \\
\text { aspects of rural economy. Some of the promises are as follows: } \\
\text { "Extend crop and animal insurance to all agricultural produce." } \\
\text { "Link support prices to the price index" } \\
\text { "Treat villages as the basic unit of development and provide each village with basic } \\
\text { facilities like roads, irrigation, drinking water, education, health and sanitation." }\end{array}$ \\
\hline
\end{tabular}


Table 5. Cont.

\begin{tabular}{|c|c|c|}
\hline No. & Criteria & BJP Election Manifesto, 1996 \\
\hline 10 & $\begin{array}{l}\text { Disapproval of or changes } \\
\text { proposed in the constitution }\end{array}$ & $\begin{array}{l}\text { BJP proposed numerous constitutional amendments in a section titled, "constitutional } \\
\text { reforms." These include: } \\
\text { "The BJP will implement the main recommendations of the Sarkaria Commission" } \\
\text { [related to Centr-eState relations] } \\
\text { "We will abrogate Article } 370 \text { of the Constitution, which puts Jammu \& Kashmir on a } \\
\text { separate and separatist pedestal" } \\
\text { "We will set up an inter-state council under Article } 263 \text { of the Constitution" } \\
\text { "We promise to carve out Uttaranchal, Vananchal, Vidarbha and Chhattisgarh and } \\
\text { give them full statehood." }\end{array}$ \\
\hline 11 & $\begin{array}{l}\text { New polity, new era, etc. } \\
\text { (demonstrating a break from } \\
\text { the present/immediate past) }\end{array}$ & $\begin{array}{l}\text { The word "new" was used ten times. Following instances demonstrate } \\
\text { populist aspects: } \\
\text { "To realise this goal, the BJP will launch a new social, economic and political order." } \\
\text { "A New Direction, A New Dispensation." } \\
\text { "It is this blueprint which will be the bedrock of a new India." }\end{array}$ \\
\hline 12 & $\begin{array}{c}\text { Name or picture of the party } \\
\text { leader }\end{array}$ & $\begin{array}{l}\text { "Vajpayee" or "Advani" not mentioned even once in the manifesto. } \\
\text { One picture of Advani or Vajpayee on the back cover. }\end{array}$ \\
\hline
\end{tabular}

In BJP's 1984 manifesto, there is no mention of a separate Indian or Hindu civilization. In the 1996 manifesto, only once there is a mention of "our civilisational and cultural consciousness." This changes in the 2009 manifesto (Table 6) when a manifest commitment to Hindutva is replaced by a pledge to India's "civilisational consciousness," that is linked to "India's cultural and civilisational greatness." The Hindutva promises (revocation of Article 370, construction of Ram Mandir, adoption of uniform civil code and cow protection) are the same but the reason is couched more broadly.

Table 6. Hindu nationalism and populism in Bharatiya Janata Party based on 2009 manifesto (BJP 2009).

\begin{tabular}{|c|c|c|}
\hline No. & Criteria & BJP Election Manifesto, 2009 \\
\hline 1 & $\begin{array}{l}\text { Support for traditional social } \\
\text { values }\end{array}$ & $\begin{array}{l}\text { "The civilisational consciousness of India has been well defined by the sages and } \\
\text { philosophers and has its roots in Bharatiya or Hindu world view ... and one can say } \\
\text { that Hinduism is the most ennobling experience in spiritual co-existence." } \\
\text { "No nation can chart out its domestic or foreign policies unless it has a clear } \\
\text { understanding about itself, its history, its strength and failings. It becomes all the more } \\
\text { important for any nation to know its roots which sustain its people in a highly mobile } \\
\text { and globalised world." } \\
\text { "What was required after independence was to reorient India's polity to bring it in } \\
\text { consonance with the seekings and sensibilities of the Indian people. Failure to do so } \\
\text { has resulted in a fractured society, vast economic disparities, terrorism and communal } \\
\text { conflict, insecurity, moral, psychological and spiritual degradation." }\end{array}$ \\
\hline 2 & Opposition to liberal lifestyles & $\begin{array}{l}\text { "It was most unfortunate that they never thought of creating a socio-economic and } \\
\text { political paradigm of governance drawing from the civilisational consciousness of } \\
\text { India. They, instead, tried to emulate whatever was being practised in this or that } \\
\text { Western country. The disastrous results are before us." }\end{array}$ \\
\hline 3 & Promotion of nationalism & $\begin{array}{l}\text { The first section of the manifesto: "To build a prosperous, powerful nation, recall } \\
\text { india's past" (capitalization in the original). } \\
\text { "These leaders had a vision to reconstruct the political and economic institutions of } \\
\text { India as a continuum of the civilisational consciousness which made India one } \\
\text { country, one people and one nation." } \\
\text { "We propose to review, revive and re-launch the National Service Scheme and } \\
\text { National Cadet Corps as effective vehicles to involve the youth in nation-building and } \\
\text { reinforcing their national spirit." }\end{array}$ \\
\hline
\end{tabular}


Table 6. Cont.

\begin{tabular}{|c|c|c|}
\hline No. & Criteria & BJP Election Manifesto, 2009 \\
\hline 4 & $\begin{array}{c}\text { Favorable toward tough law } \\
\text { and order }\end{array}$ & $\begin{array}{l}\text { BJP criticized Congress on law and order and proposed } 12 \text { measures in the first } \\
100 \text { days. Some of these measures are: } \\
\text { "Revive the anti-terror mechanism that has been dismantled by the Congress" } \\
\text { "A Digital Security Agency will be set up to deal with cyber warfare, cyber counter- } \\
\text { terrorism, and cyber security of national digital assets." } \\
\text { "Special courts will be set up for speedy prosecution of those involved with acts } \\
\text { of terrorism." } \\
\text { "The BJP will frame a law to deal with the menace of ragging [in educational } \\
\text { institutions]. All cases of ragging will be tried in fast-track courts. } \\
\text { School/college/university authorities will be held culpable for failing to implement } \\
\text { the law." }\end{array}$ \\
\hline
\end{tabular}

Favorable toward assimilation 5 for immigrants and asylum seekers
"The long-pending problems and demands of refugees from Pakistan-occupied Kashmir will be addressed."

"Internal security is also imperilled by unchecked illegal immigration across our eastern border. The vulnerability of these illegal immigrants has been time and again exploited by the ISI and its jihadi front organisations as well as local terror cells to carry out bombings and provide logistical support to foreign terrorists. The Supreme Court has described illegal immigration as an act of 'external aggression'"

"The consequences of this unabated illegal immigration are bound to be disastrous." The BJP in the first 100 days after coming to power will "launch a massive programme to detect, detain and deport illegal immigrants."

$7 \quad$ Opposition to more rights for ethnic minorities

No mention of ethnic minorities. Their existence is not even acknowledged.

"All dharmic activities will be considered as 'charity' with appropriate tax incentives. A special cell will be created to make dharmic organisations' interface with government agencies hassle-free."

$8 \quad$ Support for religious principles in politics

"The BJP will explore all possibilities, including negotiations and judicial proceedings, to facilitate the construction of the Ram Temple in Ayodhya."

"In view of the recent judgement by the constitutional bench of the Supreme Court, and in keeping with the Directive Principles of State Policy as contained in the

Constitution, necessary legal framework will be created to protect and promote cow and its progeny."

"The BJP views food security as integral to national security. The spectre of a looming food crisis haunts the developing world as never before. With the agriculture sector suffering on account of the Congress' gross negligence, India faces a real threat of food scarcity."

9 Support for rural interests

"There are three immediate concerns which will be addressed by the BJP in a time-bound manner: Ensuring assured income for farmers; freeing farmers from the burden of mounting debts; and, increasing public investment in agriculture. Everything can wait, but not agriculture."

BJP proposed following constitutional amendments:

“The BJP proposes to introduce an amendment to the Constitution to make it mandatory for Government to seek Parliament's approval/ratification by two-thirds majority before signing any bilateral or multilateral agreement that impinges on India's strategic programmes"

10 Disapproval of or changes proposed in the constitution
"Work for the effective financial and administrative empowerment of Panchayati Raj institutions and Urban Local Bodies in respect of funds, functions and functionaries.

There will be further devolution of powers by amending the Constitution."

"Article 370 poses a psychological barrier for the full integration of the people of Jammu \& Kashmir with the national mainstream. The BJP remains committed to the abrogation of this Article."

“The BJP remains committed to 33 per cent political representation for women, and shall act on this after coming to power." 
Table 6. Cont.

\begin{tabular}{|c|c|c|}
\hline No. & Criteria & BJP Election Manifesto, 2009 \\
\hline 11 & $\begin{array}{l}\text { New polity, new era, etc. } \\
\text { (demonstrating a break from } \\
\text { the present/immediate past) }\end{array}$ & $\begin{array}{l}\text { The word "new" was used } 15 \text { times but few of these demonstrate populist aspects } \\
\text { Some of those that do exhibit populist disposition are given below: } \\
\text { "The situation needs a change and a new paradigm is called for, for creating a } \\
\text { prosperous, progressive and powerful India" } \\
\text { "Science and technology, we believe, should be used to build a new and resurgent } \\
\text { India" }\end{array}$ \\
\hline 12 & $\begin{array}{c}\text { Name or picture of the party } \\
\text { leader }\end{array}$ & $\begin{array}{l}\text { "Advani" was mentioned three times in the manifesto while "Vajpayee" was } \\
\text { mentioned five times. } \\
\text { Only one picture of Advani but he is not the only one. Vajpayee and Rajnath Singh } \\
\text { (then BJP president)'s pictures are also on the title page. }\end{array}$ \\
\hline
\end{tabular}

The 2019 manifesto (Table 7) is different from the previous manifestos in two respects as far as Hindutva is concerned. First, BJP's Hindutva had made peace with modernity in this manifesto. In the previous manifestos (1984, 1996 and 2009), it disparaged Western values or emulation of the West or vulgarity or drinking alcohol. Although the BJP is still committed to the civilizational ethos of India and sees cultural values as essential ingredients of the future, there are no specific cultural values that the manifesto wants to preserve. Second, in the 2019 manifesto, the attack on Muslim concerns have been broadened. In case of Kashmir, not only Article 370 of the constitution but Article 35A has also been selected for abrogation. Furthermore, in order to "save" Muslim women from discrimination, the BJP promised to bring laws to end Muslim practices of triple talaq and nikah halala.

Table 7. Hindu nationalism and populism in Bharatiya Janata Party based on 2019 manifesto (BJP 2019).

\begin{tabular}{|c|c|c|}
\hline No. & Criteria & BJP Election Manifesto, 2019 \\
\hline 1 & $\begin{array}{l}\text { Support for traditional social } \\
\text { values }\end{array}$ & $\begin{array}{l}\text { "We will undertake every effort to ensure that the subject of faith, tradition and } \\
\text { worship rituals related to Sabarimala are presented in a comprehensive manner before } \\
\text { the Hon'ble Supreme Court." } \\
\text { "The BJP reiterates its stand to draft a Uniform Civil Code, drawing upon the best } \\
\text { traditions and harmonizing them with the modern times." } \\
\text { "Since inception, the philosophy of the BJP is anchored in the civilisational ethos of } \\
\text { India. As we build 'New India', we intend to actively invest in strengthening our } \\
\text { cultural roots and preserving civilisational continuity. Far from seeing our cultural } \\
\text { values as hurdles to progress, we see them as essential ingredients of our future." }\end{array}$ \\
\hline 2 & Opposition to liberal lifestyles & \\
\hline 3 & Promotion of nationalism & $\begin{array}{l}\text { PM Modi in his letter (part of manifesto) talked about "the nation is no longer helpless } \\
\text { against the barbaric forces of terror," transforming "our great nation," BJP's resolve } \\
\text { "to build a stronger, safer and prosperous nation." } \\
\text { BJP president Amit Shah in his note declared, "Every single word written in our } \\
\text { manifesto signifies our commitment to the nation and its people." } \\
\text { The very first chapter in the manifesto is titled "Nation first." }\end{array}$ \\
\hline 4 & $\begin{array}{l}\text { Favorable toward tough law } \\
\text { and order }\end{array}$ & $\begin{array}{l}\text { Manifesto's first commitment and promises are related to national security, both } \\
\text { internal and external. } \\
\text { BJP pledged "zero-tolerance to terrorism and extremism and will continue to follow } \\
\text { our policy of giving a free hand to our security forces in combating terrorism." } \\
\text { "We will continue to take forward the process of modernizing the Central Armed } \\
\text { Police Forces to further increase their capacity and readiness and enable them to } \\
\text { effectively combat internal security challenges." } \\
\text { "Women's security will be given more priority. We have constituted the Women's } \\
\text { Security Division in the Home Ministry, and have made strict provisions for } \\
\text { transferring the laws in order to prevent crimes against women, in particular in a } \\
\text { time-bound investigation and trial of rape." }\end{array}$ \\
\hline
\end{tabular}


Table 7. Cont.

\begin{tabular}{|c|c|c|}
\hline No. & Criteria & BJP Election Manifesto, 2019 \\
\hline 5 & $\begin{array}{l}\text { Favorable toward assimilation } \\
\text { for immigrants and asylum } \\
\text { seekers }\end{array}$ & $\begin{array}{l}\text { "We will provide financial assistance for the resettlement of refugees" from Pakistan } \\
\text { and Chhamb. }\end{array}$ \\
\hline 6 & $\begin{array}{l}\text { Support for restrictive } \\
\text { immigration policies }\end{array}$ & $\begin{array}{c}\text { "There has been a huge change in the cultural and linguistic identity of some areas } \\
\text { due to illegal immigration ... We will expeditiously complete the National Register of } \\
\text { Citizens process in these areas on priority. In future we will implement the NRC in a } \\
\text { phased manner in other parts of the country." } \\
\text { "We will continue to undertake effective steps to prevent illegal immigration in the } \\
\text { Northeastern states." }\end{array}$ \\
\hline 7 & $\begin{array}{l}\text { Opposition to more rights for } \\
\text { ethnic minorities }\end{array}$ & No mention of ethnic minorities. Their existence is not even acknowledged. \\
\hline 8 & $\begin{array}{l}\text { Support for religious } \\
\text { principles in politics }\end{array}$ & $\begin{array}{c}\text { "We reiterate our stance on Ram Mandir. We will explore all possibilities within the } \\
\text { framework of constitution ... to facilitate the expeditious construction of the } \\
\text { Ram Temple." } \\
\text { "We are committed to the enactment of the Citizenship Amendment Bill for the } \\
\text { protection of individuals of religious minority communities from neighbouring } \\
\text { countries escaping persecution." } \\
\text { "With a focused effort on promotion of Sanskrit, we will ensure that the teaching of } \\
\text { Sanskrit is expanded and popularized in the schools." } \\
\text { "Continuing our work, we will legislate a bill to prohibit and eliminate practices such } \\
\text { as Triple Talaq and Nikah Halala." } \\
\text { "Ensure justice for Muslim women by enacting the law against triple talaq." } \\
\text { "Therefore, we hope to modernize personal laws to prohibit practices such as } \\
\text { Talaq-e-Biddat and Nikah Halala." }\end{array}$ \\
\hline 9 & Support for rural interests & $\begin{array}{l}\text { More than } 25 \text { promises related to different aspects of rural development, including the } \\
\text { principal promise of doubling farmer's income by } 2022 .\end{array}$ \\
\hline 10 & $\begin{array}{l}\text { Disapproval of or changes } \\
\text { proposed in the constitution }\end{array}$ & $\begin{array}{c}\text { "We reiterate our position since the time of the Jan Sangh to the abrogation of } \\
\text { Article 370." } \\
\text { "We are committed to annulling Article 35A of the Constitution of India as the } \\
\text { provision is discriminatory against non-permanent residents and women of Jammu } \\
\text { and Kashmir." } \\
\text { "Women's welfare and development will be accorded a high priority at all levels } \\
\text { within the government, and the BJP is committed to 33\% reservation in parliament } \\
\text { and state assemblies through a constitutional amendment." } \\
\text { "We will endeavour to secure constitutional protection on issues related to faith } \\
\text { and belief." }\end{array}$ \\
\hline 11 & $\begin{array}{l}\text { New polity, new era, etc. } \\
\text { (demonstrating a break from } \\
\text { the present/immediate past) }\end{array}$ & $\begin{array}{c}\text { The word "new" was used } 13 \text { times and most of the times it is capitalized. Following } \\
\text { instances demonstrate populist aspects: } \\
\text { Title of PM Modi's speech: "A New India of 130 CRORE DREAMS." (Capitalization } \\
\text { from the original) } \\
\text { "New India has broken from the shackles of the past." } \\
\text { "Narendra Modi led BJP government is the harbinger of a new India." } \\
\text { Manifesto starts with, "Towards a New India." } \\
\text { 'Sabka Saath, Sabka Vikas' is at the heart of PM Modi's vision of New India." }\end{array}$ \\
\hline 12 & $\begin{array}{l}\text { Name or picture of the party } \\
\text { leader }\end{array}$ & $\begin{array}{l}\text { "Modi" was mentioned } 31 \text { times in the manifesto. } \\
\text { There are six pictures of PM Modi, including one on the title page. }\end{array}$ \\
\hline
\end{tabular}

To ascertain the increase or decrease in Hindu populism, the focus now shifts to the last three criteria. Analyzing Hindu Mahasabha's manifesto, the first criteria of populism about disapproval of constitution, there is strong sign of populism but in the other two criteria, Hindu Mahasabha fares poorly. There is not much use of or promise of a "new" India and the name or picture of the leader is non-existent.

In its 1967 manifesto, the BJS moved closer to take on the mantle of a Hindutva populist party. It called for amendments in the constitution and also promised a new era repeatedly. 
However, the personalization of politics is missing. Pandit Deen Dayal Upadhyaya is considered one of the top ideologues of Hindutva but was given less importance than the party. In the 1971 manifesto, the BJS stand on constitution moved a step further as it asked not only for individual amendments but also a constitution commission to review the whole constitution. Although the word "new" was used less, the BJS called for "a brave new India." Again, as in 1967, the major deficiency as far as populism was concerned was the lack of personalization of politics. There was no mention or picture of the party president Atal Bihari Vajpayee.

The BJP was not always a populist party. In its 1984 manifesto, the first manifesto after it was established, the BJP approves the constitution and uses the word "our" to demonstrate a close relationship. Only one amendment was proposed and that was removal of Article 370 related to Kashmir. The BJP also does not fare well based on the third criteria of personalization of politics. BJP's president's name was used only once and there was perhaps only one picture of him. The reference to him is also diluted by the manifesto writers by mentioning "collective leadership." Only on the basis of the second criteria, the BJP behaved as a populist party. The word "new" is used nine times and shows a significant break from the past as BJP called for a "new India" and a "new polity".

In the 1996 manifesto, the affinity with the constitution shown in 1984 is gone. A large number of constitutional amendments were proposed by the BJP. The word "new" was used ten times and called for a "new direction" and "a new social, economic and political order." The personalization of politics is, however, again absent as the name of the president is not mentioned and there is probably a single picture of Advani on the back cover.

In the 2009 manifesto, Hindu populism appears to gain ground. There are several constitutional amendments proposed and some of them appear for the first time in the Hindutva parties' manifestos studied in this article. For instance, amendments seeking 33\% representation of women in legislatures and the requirement of a two-third majority for the ratification of international agreements was not present in any of the previous manifestos. The word "new" was also used 15 times and at least twice it was used in a very broad sense promising a break from the country's past. Finally, this manifesto also had names and pictures of current and previous BJP leaders.

The 2019 manifesto is the most populist manifesto. A number of constitutional amendments are proposed, some of which are new. The word "new" is used 13 times, which is less than its usage in the 2009 manifesto, but what is significant is that most of the time "new" has been in a broad sense. The BJP is promising new airports and schools but most of the time it is promising to establish "New India" and most of the time it is capitalized. The major change was, however, seen in the last criteria of personalized politics. PM Modi looms large in this manifesto. His name appears 31 times and there are six pictures of him in the document, including one each on the title and last page.

From the above analysis, it is clear that BJP's current nationalist-populist framework was not always part of BJP's strategy. Previously, the focus was only on (Hindu) nationalism without much populism (Yilmaz et al. 2021). In the 1984 and 1996 manifestos, the presence of populism was limited. It is in the 2009 manifesto that one detects a surge in populism and in the 2019 manifesto, Hindu populism is in full bloom.

\section{Conclusions}

The above discussion highlights the differences between Hindutva or Hindu nationalism and Hindu populism in the manifestos of the most successful rightwing Indian parties. More broadly, it underscores the fact that while Hindu nationalism and populism presently overlap in Modi's India, it was not always so in the past. The article also explores how Hinduism, an amorphous religion that was not suited for a role of "thick" ideology, was instrumentalized. Finally, it successfully uses methodologies developed for European countries to decipher Indian politics, Indian nationalism and Indian populism. 
Future research can investigate the interplay of Hindu nationalism and populism in Nepal, the only other Hindu majority state in the world. The criteria framework developed in the article can also be used to distinguish between religious nationalist and religious populist politics in other countries. There are numerous countries where one sees an amalgam of religious nationalism and religious populism. Turkey, under President Erdogan and his party AKP, is a prime example of a successful fusion of Muslim nationalism and populism and, as in the case of India, most analysts do not distinguish between Muslim nationalism and populism in Turkey. In Europe, the manifestos of Polish ruling party, the rightwing Law and Justice Party, can be dissected to distinguish between the rise of Christian populism and Christian nationalism. Finally, one can scrutinize the rise of Jewish populism under former Prime Minister Netanyahu in the rightwing nationalist Likud Party and how it helped Netanyahu to rule for more than a decade and become the longest serving prime minister of Israel.

Funding: This research received no external funding.

Institutional Review Board Statement: Not applicable.

Informed Consent Statement: Not applicable.

Data Availability Statement: Not applicable.

Conflicts of Interest: The author declares no conflict of interest.

\section{Note}

1 The term rightwing is used here as a convinience and with the acknowledgement that it is very difficult to divide politics into rightwing and leftwing. There are innumerable ways by which the division between leftwing and rightwing politics have been defined and numerous differences within what is called leftwing or rightwing. Therefore, instead of trying to define leftwing or rightwing politics, I will try to explain what leftwing-rightwing dichotomy means in this article. I will follow here professor's lead and define leftwing politics as the primacy of a thick, expansive socio-political ideal of equality while rightwing, while adhering to its version of equality, does not accept the primacy or thickness of the equality ideal (Lukes 2003, pp. 609-16). In the Indian context, for this article, rightwing politics will, hence, include politics of those who give primacy to a particular tradition, specific religion or other hierarchical ideology.

\section{References}

Andersen, Walter, and Shridhar D. Damle. 1987. The Brotherhood in Saffron: The RSS and Hindu Revivalism. New Delhi: Vistaar Publications.

Andersen, Walter, and Shridhar D. Damle. 2019. Messengers of Hindu Nationalism: How the RSS Reshaped India. London: Hurst \& Company.

Balagangadhara, S. N. 1994. 'The Heathen in His Blindness...': Asia, the West, and the Dynamic of Religion. Leiden: Brill.

Bapu, Prabhu. 2013. Hindu Mahasabha in Colonial North India, 1915-1930: Constructing Nation and History. New York: Routledge.

Basu, Anustup. 2020. Hindutva as Political Monotheism. Durham: Duke University Press.

Baudner, Jorg. 2018. Populism, Personalization and De-Institutionalization. Paper present at ECPR Joint Sessions, Nicosia, Cyprus, April 10-14.

BJP. 1984. Towards a New Polity. Manifesto Lok Sabha Election-1984. New Delhi: BJP.

BJP. 1996. BJP Election Manifesto 1996. New Delhi: BJP.

BJP. 2009. Bharatiya Janata Party: Good Governance, Development, Security. Manifesto Lok Sabha Election 2009. New Delhi: BJP.

BJP. 2019. Sankalpit Bharat Sashakt Bharat Bharatiya Janata Party Sankalp Patra Lok Sabha 2019. New Delhi: BJP.

BJS. 1967. Bharatiya Jana Sangh Election Manifesto 1967. New Delhi: Arjun Press.

BJS. 1971. Jana Sangh Declares ... War on Poverty: Election Manifesto, 1971. New Delhi: BJS Central Office.

Brittain, Christopher Craig. 2018. Racketeering in religion: Adorno and evangelical support for Donald Trump. Critical Research in Religion 6: 269-88. [CrossRef]

Brubaker, Rogers. 2017. Between nationalism and civilizationism: The European populist moment in comparative perspective. Ethnic and Racial Studies 40: 1191-226. [CrossRef]

Chakrabarti, Kaustuv, and Kaustuv K. Bandyopadhyay. 2021. Populism in Contemporary Indian Politics. In Populism in Asian Democracies: Features, Structures, and Impacts. Edited by Sook Jong Lee, Chin-en Wu and Kaustuv K. Bandyopadhyay. Boston: Brill. 
Chandrababu, Divya. 2021. Tamil Nadu's freebie culture is here to stay, say parties, experts. Hindustan Times, March 15. Available online: https: / www.hindustantimes.com/elections/tamil-nadu-assembly-election/tamil-nadu-s-freebie-culture-is-here-tostay-say-parties-experts-101615543899074.html (accessed on 30 May 2021).

Collinson, Stephen. 2021. COVID-19 Exposed Populist Leaders Like Modi and Trump. Washington Post, April 26. Available online: https:/ / edition.cnn.com/2021/04/26/world/meanwhile-in-america-populism/index.html (accessed on 19 May 2021).

Doniger, Wendy. 2009. The Hindus: An Alternative History. New York: Oxford University Press.

Doniger, Wendy. 2014. On Hinduism. New York: Oxford University Press.

Flood, Gavin. 1996. An Introduction to Hinduism. Cambridge: Cambridge University Press.

Frawley, David. 2018. What is Hinduism?: A Guide for the Global Mind. New Delhi: Bloomsbury India.

Friedman, Uri. 2021. COVID-19 Lays Bare the Price of Populism: A Raging Outbreak in Brazil Threatens Gains against the Virus. The Atlantic, May 9. Available online: https:/ /www.theatlantic.com/ideas/archive/2021/05/covid-19-lays-bare-price-populism/61 8838/ (accessed on 15 May 2021).

Gandhi, M. K. 2021. RamRajya. Available online: https:/ / www.mkgandhi.org/momgandhi/chap67.htm (accessed on 5 June 2021).

Gianolla, Cristiano. 2020. Undermining Populism through Gandhi's Intercultural Democratic Discourse. Journal of Multicultural Studies 15: 1. Available online: https://www.tandfonline.com/doi/full/10.1080/17447143.2020.1734011 (accessed on 31 May 2021). [CrossRef]

Grzymala-Busse, Anna. 2012. Why Comparative Politics Should Take Religion (More) Seriously. Annual Review of Political Science 15: 421-42. [CrossRef]

Guha, Ramachandra. 2021. Modi's Hindutva Irrationality Makes India's War on COVID-19 even more Difficult. Scroll.in, May 23. Available online: https:/ / scroll.in/article/995510/ramachandra-guha-modis-hindutva-irrationality-makes-indias-war-oncovid-19-even-more-difficult (accessed on 27 May 2021).

Hadiz, Vedi R. 2018. Imagine All the People? Mobilising Islamic Populism for Right-Wing Politics in Indonesia. Journal of Contemporary Asia 48: 566-83. [CrossRef]

Hindu Mahasabha. 1966. Election Manifesto of Akhil Bharat Hindu Mahasabha. New Delhi: Hindu Mahasabha.

Huntington, Samuel. 1993. The Clash of Civilizations? Foreign Affairs 73: 3. [CrossRef]

Jacobs, Stephen. 2010. Hinduism Today. London: Continuum International Publishing Group.

Jaffrelot, Christophe. 2007. Introduction. In Hindu Nationalism A Reader. Edited by Christophe Jaffrelot. Princeton: Princeton University Press.

Jaffrelot, Christophe, and Louise Tillin. 2017. Populism in India. In The Oxford Handbook of Populism. Edited by Cristobal Kaltwasser, Paul Taggart, Paulina Espeho and Pierre Ostiguy. Oxford: Oxford University Press, pp. 179-94.

Kirchner, Emil, ed. 1988. Liberal Parties in Western Europe. Cambridge: Cambridge University Press.

Kumar, Sajjan. 2019. The Limits of Populism. The Hindu, April 18. Available online: https://www.thehindu.com/opinion/lead/thelimits-of-populism/article26867609.ece (accessed on 25 May 2021).

Libbrecht, Liselotte, Bart Maddens, W. Swenden, and E. Fabre. 2009. Issue salience in regional party manifestos in Spain. European Consortium of Political Research 48: 58-79. [CrossRef]

Liddiard, Patrick. 2019. Is Populism Really a Problem for Democracy? History and Public Policy Occasional Papers. Woodrow Wilson Center. Available online: https:/ / www.wilsoncenter.org/sites/default/files/media/documents/publication/liddiard_ is_populism_really_a_problem_for_democracy_august_2019_0.pdf (accessed on 22 May 2021).

Lukes, Steven. 2003. Epilogue: The grand dichotomy of the twentieth century. In The Cambridge History of Twentieth-Century Political Thought. Edited by Terence Ball and Richard Bellamy. Cambridge: Cambridge University Press.

Mackert, Juergen. 2019. Introduction: Is there such a thing as Populism? In Populism and the Crisis of Democracy. Volume 1: Concepts and Theory. Edited by Gregor Fitzi, Juergen Mackert and Bryan Turner. New York: Routledge.

Mahapatra, Dhananjay. 2018. How Supreme Court viewed words 'Hindu', 'Hinduism' and 'Hindutva' in rulings. The Times of India, February 5. Available online: http:/ / timesofindia.indiatimes.com/articleshow/62782807.cms?utm_source=contentofinterest\& utm_medium=text\&utm_campaign=cppst (accessed on 21 May 2021).

Pandey, Neelam, and Tarun Krishna. 2020. Kejriwal Promises Freebies for Delhi Ahead of Elections, but Many Voters Don't Want It. The Print, February 7. Available online: https:/ theprint.in/india/arvind-kejriwals-freebies-a-hit-in-slums-but-there-are-manysceptics-outside/361248/ (accessed on 29 May 2021).

Pennings, Paul. 2006. An Empirical Analysis of the Europeanization of National Party Manifestos, 1960-2003. European Union Politics 7: 257-70. [CrossRef]

Pew Research Center. 2019. European Public Opinion Three Decades after the Fall of Communism. Washington, DC: Pew Research Center.

Plagemann, Johannes, and Sandra Destradi. 2019. Populism and Foreign Policy: The Case of India. Foreign Policy Analysis 15: $283-301$. [CrossRef]

Roberts, Kenneth. 2017. Populism and Political Parties. In The Oxford Handbook of Populism. Edited by Cristobal Kaltwasser, Paul Taggart, Paulina Espeho and Pierre Ostiguy. Oxford: Oxford University Press, pp. 287-304.

Roover, Jacob. 2019. A new school in the study of India? Contemporary South Asia 27: 273-85. [CrossRef]

Saleem, Raja M. 2019. Religious Values and Worldview. Oxford Research Encyclopedia. Available online: https: / / oxfordre.com/ politics/view/10.1093/acrefore/9780190228637.001.0001/acrefore-9780190228637-e-1158 (accessed on 26 May 2021). 
Santoshini, Sarita, Ana Ionova, and Sara Miller Llana. 2021. Global Populism: Big Promises, Poor Pandemic Results. Christian Science Monitor, April 30. Available online: https://www.csmonitor.com/World/2021/0430/Global-populism-Big-promises-poorpandemic-results (accessed on 1 June 2021).

Subramanian, Narendra. 2007. Populism in India. SAIS Review of International Affairs 27: 81-91. [CrossRef]

Thapar, Romila. 2000. Cultural Pasts: Essays in Early Indian History. New Delhi: Oxford University Press.

Tharoor, Shashi. 2018. Why I Am a Hindu? Brunswick: Scribe Publications.

Tripathi, Salil. 2009. Offence. The Hindu Case. London: Seagull Books.

Visana, Vikram. 2020. Savarkar before Hindutva: Sovereignty, Republicanism, and Populism in India, c.1900-1920. Modern Intellectual History 1-24. Available online: https:/ / www.cambridge.org/core/journals/modern-intellectual-history/article/abs/savarkarbefore-hindutva-sovereignty-republicanism-and-populism-in-india-c19001920/90DC611F3F01B05C2FE4ECC61BECDC73 (accessed on 30 May 2021). [CrossRef]

Viswanath, Sunita. 2021. Modi's Religious Nationalism Hurts India's Hindus, Too. Foreign Policy, May 26. Available online: https:/ / foreignpolicy.com/2021/05/26/modi-hindu-nationalism-hindutva-hurts-hindus-too/ (accessed on 3 June 2021).

Von Stietencron, Heinrich. 2001. Hinduism: On the Proper Use of a Deceptive Term. In Hinduism Reconsidered. Edited by G. Sontheimer and H. Kulke. New Delhi: Manohar.

Wilberg, Acharya Peter. 2009. What Is Hinduism. Scotts Valley, California: CreateSpace Publishers.

Yilmaz, Ihsan. 2018. Islamic Populism and Creating Desirable Citizens in Erdogan's New Turkey. Mediterranean Quarterly 29: 52-76. [CrossRef]

Yilmaz, Ihsan. 2021. The AKP's Authoritarian, Islamist Populism: Carving out a New Turkey. ECPS Party Profile Series No. 4. Available online: https:/ / www.populismstudies.org/the-akps-authoritarian-islamist-populism-carving-out-a-new-turkey / (accessed on 3 June 2021).

Yilmaz, Ihsan, and Galib Bashirov. 2018. The AKP after 15 years: Emergence of Erdoğanism in Turkey. Third World Quarterly 39: 1812-30. [CrossRef]

Yilmaz, Ihsan, and Nicholas Morieson. 2021. A Systematic Literature Review of Populism, Religion and Emotions. Religions 12: 272. [CrossRef]

Yilmaz, Ihsan, and Raja M. Ali Saleem. 2021. A Quest for Identity: The Case of Religious Populism in Pakistan. ECPS. Available online: https:/ / www.populismstudies.org/a-quest-for-identity-the-case-of-religious-populism-in-pakistan/ (accessed on 2 June 2021).

Yilmaz, Ihsan, and Kainat Shakeel. 2021. Imran Khan: From Cricket Batsman to Populist Captain Tabdeli of Pakistan. ECPS. Available online: https: / / www.populismstudies.org/imran-khan-from-cricket-batsman-to-populist-captain-tabdeli-of-pakistan/ (accessed on 30 May 2021).

Yilmaz, Ihsan, Nicholas Morieson, and Mustafa Demir. 2021. Exploring Religions in Relation to Populism: A Tour around the World. Religions 12: 301. [CrossRef] 